\title{
EVALUASI PROGRAM TALENT SCOUTING GURU SMK TAHUN 2013 DIREKTORAT P2TK DIKMEN KEMDIKBUD
}

\author{
Roudlotus Sholikhah \\ Universitas Negeri Semarang \\ annajihah_qudsy@yahoo.co.id \\ Soenarto \\ Universitas Negeri Yogyakarta \\ narto_elka@yahoo.com
}

\begin{abstract}
Abstrak
Penelitian ini bertujuan untuk mengetahui: (1) relevansi pelaksanaan Program Talent Scouting Guru SMK tahun 2013 ditinjau dari aspek konteks; (2) kesesuaian pelaksanaan Program Talent Scouting Guru SMK tahun 2013 ditinjau dari aspek input; (3) efektifitas pelaksanaan Program Talent Scouting Guru SMK tahun 2013 ditinjau dari aspek proses; dan (4) pencapaian hasil pelaksanaan Program Talent Scouting Guru SMK tahun 2013 ditinjau dari aspek produk. Jenis penilitian ini adalah evaluasi program dengan model evaluasi CIPP (Context, Input, Process, Product). Hasil penelitian: (1) pencapaian relevansi program termasuk dalam kategori "sangat relevan" dengan persentase pencapaian $85 \%$; (2) kesesuaian input SMK sasaran program, peserta program dan penyelenggara program termasuk dalam kategori "sesuai" dengan persentase pencapaian 76,38\%; (3) keefektifan proses sosialisasi, seleksi dan pembekalan, proses pelaksanaan program serta proses monitoring dan pelaporan termasuk dalam kategori "efektif" dengan persentase pencapaian 74,52\%; (4) pencapaian produk teaching dan non teaching termasuk dalam kategori "sangat tercapai" dengan persentase pencapaian $84,35 \%$.
\end{abstract}

Kata kunci: Program Talent Scouting Guru SMK, Evaluasi, CIPP.

\section{AN EVALUATION OF THE TALENT SCOUTING PROGRAM FOR SMK TEACHERS IN 2013 DIREKTORAT P2TK DIKMEN KEMDIKBUD}

\begin{abstract}
This study aims to know: (1) the relevance of the Talent Scouting program for SMK teachers in 2013 in terms of the aspect of context, (2) the appropriateness of the Talent Scouting program for SMK teacher in 2013 in terms of the aspect of input, (3) the effectiveness of the Talent Scouting program for SMK teacher in 2013 in terms of the aspect of process, and (4) the attainment of the Talent Scouting program for SMK teacher in 2013 in terms of the aspect of product. This research is an evaluation of the program using CIPP (Context, Input, Process, Product) evaluation model. The results of this study: (1) the relevance of the program achievement is included in the category of "very relevant" with the achievement percentage of $85 \%$, (2) the input appropriateness of vocational program targets, program participants and program providers are included in the category of "appropriate" with the percentage achieved is $76.38 \%$, (3) the effectiveness of the process of socialization, selection and provisioning, implementation process, monitoring and reporting process are included in the category of "effective" with the achievement percentage of $74.52 \%$, (4) teaching and non-teaching product attainment are included in the category of "very attainable" with the achievement percentage of $84.35 \%$.
\end{abstract}

Keywords: Talent Scouting Program for SMK teachers, Evaluation, CIPP. 


\section{PENDAHULUAN}

Pendidikan Kejuruan menurut Clarke dan Winch adalah: "Vocational education is confined to preparing young people and adults for working life, a process often regarded as of a rather technical and practical nature". Pendidikan kejuruan adalah pendidikan yang menyiapkan anak-anak muda dan orang dewasa untuk memasuki lapangan kerja, pendidikan kejuruan adalah suatu proses yang dalam pembelajarannya berkaitan dengan masalah teknik dan praktik (Clarke \& Winch, 2007, p.90).

Pavlova mendiskripsikan pendapat Sanders dan Stevenson tentang pendidikan kejuruan sebagai berikut: “... conceptualisations of vocational education are related to skill in using tools and machines (Sander, 2001), Steven (2003) vocational education is identified a number of dichotomies in these underlying assumptions. These include general knowledge versus specific knowledge; theoretical knowledge versus practical/functional knowledge; conceptual understanding versus proficiency in skills; creative abilities versus reproductive abilities; ratio intellectual skills versus physical skills; preparation for life versus preparation for work". Pendapat tersebut memiliki makna bahwa pendidikan kejuruan berkaitan erat dengan ketrampilan menggunakan alat atau mesin, pendidikan kejuruan diidentifikasikan pada asumsi dikotomi yaitu pengetahuan umum lawan pengetahuan khusus; pengetahuan teori lawan praktik; pemahaman konsep lawan pemilikan keterampilan; kemampuan kreatif lawan kemampuan reproduktif; ketrampilan intelektual lawan kemampuan fisik; persiapan untuk kehidupan lawan persiapan untuk bekerja (Pavlova, 2009, p.45).

Dalam Pasal 15 Undang-undang Sisdiknas Nomor 20 Tahun 2003 dijelaskan pendidikan kejuruan merupakan pendidikan menengah yang mempersiapkan peserta didik terutama untuk bekerja dalam bidang tertentu. Kemudian dalam Peraturan Pemerintah Nomor 29 tahun 1990 merumuskan bahwa Pendidikan Menengah Kejuruan mengutamakan penyiapan siswa untuk memasuki lapangan kerja serta mengembangkan sikap professional.

Pendidikan kejuruan menurut Sudira memiliki tiga manfaat utama yaitu: (1) bagi peserta didik sebagai peningkatan kualitas diri, peningkatan peluang mendapatkan pekerjaan, peningkatan peluang berwirausaha, peningkatan penghasilan, penyiapan bekal pendidikan lebih lanjut, penyiapan diri bermasyarakat, berbangsa, bernegara, penyesuaian diri terhadap perubahan dan lingkungan; (2) bagi dunia kerja dapat memperoleh tenaga kerja berkualitas tinggi, meringankan biaya usaha, membantu memajukan dan mengembangkan usaha; dan (3) bagi masyarakat dapat meningkatkan kesejahteraan masyarakat, meningkatkan produktivitas nasional, meningkatkan penghasilan negara, dan mengurangi pengangguran (Sudira, 2009, p.6).

Berdasarkan pendapat para ahli diatas, dapat disimpulkan bahwa pendidikan kejuruan merupakan pendidikan formal untuk jenjang pendidikan menengah yang bermaksud menyiapkan peserta didik untuk memasuki lapangan kerja yang sesuai dengan tuntutan yang dipersyaratkan oleh dunia kerja dan memberikan bekal kepada peserta didik untuk mengembangkan dirinya.

Sejak tahun 1998, Pemerintah melakukan reformasi pendidikan kejuruan yang ditekankan pada dua hal. Pertama, memanfaatkan potensi lokal, mulai dari sumber daya alam, mineral, pertanian, dan perikanan. Kedua, meningkatkan relevansi kompetensi lulusan dengan kebutuhan dunia kerja. Perkembangan terakhir menunjukkan bahwa pemerintah terus mengembangkan pendidikan menengah, terutama pendidikan kejuruan dengan terus meningkatkan jumlah sekolah kejuruan di berbagai wilayah di Indonesia. Salah satu kebijakan Departemen Pendidikan Nasional adalah pencanangan program peningkatan jumlah SMK yaitu pencapaian proporsi SMK dan SMA yang diharapkan menjadi 70:30 pada tahun 2015.

Untuk mencapai jumlah SMK yang lebih banyak dari SMA yaitu 70:30 pada tahun 2015, maka dalam kurun waktu ke depan akan banyak dibutuhkan tenaga pendidik dan tenaga kependidikan, pembangunan Unit Sekolah Baru (USB) dan ruang sekolah baru untuk SMK. Dalam rangka merealisasikan target yang telah dicanangkan tersebut, sejak tahun 2003 sampai dengan 2013 lebih dari 400 USB sudah didirikan di berbagai Kabupaten/Kota 
di Indonesia. Sekolah-sekolah ini tentunya harus terus dibantu baik dari segi proses pembelajaran, sarana-prasarananya maupun dalam hal pemenuhan guru khususnya guru produktif SMK.

Menurut UU RI No. 14 tahun 2005 tentang Guru dan Dosen pada pasal 1 dinyatakan bahwa guru adalah pendidik professional dengan tugas utama mendidik, mengajar, membimbing, mengarahkan, menilai dan mengevaluasi peserta didik pada pendidikan anak usia dini jalur pendidikan formal, pendidikan dasar dan pendidikan menengah. Menurut Zamroni, guru adalah orang yang memegang peran penting dalam merancang strategi pembelajaran yang akan dilakukan. Keberhasilan proses pembelajaran sangat tergantung pada penampilan guru dalam mengajar dan kegiatan mengajar dapat dilakukan dengan baik dan benar oleh seseorang yang telah melewati pendidikan tertentu yang memang dirancang untuk mempersiapkan sebagai seorang guru (Zamroni, 2001, p.60).

Pernyataan tersebut mengantarkan kepada pengertian bahwa mengajar adalah suatu profesi, dan pekerjaan guru adalah pekerjaan profesional. Setiap guru yang professional juga dipersyaratkan harus memiliki kemampuan atau kompetensi tertentu agar yang bersangkutan dapat melaksanakan tugas profesionalnya. Smith menyatakan guru pendidikan kejuruan (SMK) harus memiliki kemandirian, memiliki dorongan motivasi yang kuat dalam bekerja, termasuk penguasaan terhadap kaidah-kaidah profesionalisme pendidikan kejuruan dalam memperbaiki kompetensi pengajarannya (Smith, 2009, p.12). Guru pendidikan kejuruan menurut Beven harus kompeten dalam merancang pembelajaran yang sarat dengan pemberian pengalaman kepada anak didik melalui penguasaan kaidah-kaidah pedagogik dan kurikulum pendidikan kejuruan (Beven, 2009, p.5).

Fisher dan Webb mendefiniskan kompetensi adalah: "a competency is more than just knowledge and skills. It involves the ability to meet complex demands, by drawing on and mobilising psychosocial resources (including skills and attitudes) in a particular context". Kompetensi tidak sekedar pengetahuan dan keterampilan tetapi lebih dari itu. Kompetensi mencakup kemampuan memenuhi permintaan yang komplek dengan menggunakan dan memobilisasi sumberdaya psikologis seperti keterampilan dan sikap pada konteks yang tepat (Fisher, R. \& Webb, K., 2006, p.4). Selanjutnya Definition and Selection of Competencies (DeSeCo, 2003, p.5) mendefinisikan arti kompetensi sebagai berikut: "a competency is more than just knowledge and skills. It involves the ability to meet complex demands, by drawing on and mobilising psychosocial resources (including skills and attitudes) in a particular context”. Kompetensi tidak sekedar pengetahuan dan keterampilan tetapi lebih dari itu. Kompetensi mencakup kemampuan memenuhi permintaan yang komplek dengan menggunakan dan memobilisasi sumberdaya psikologis seperti keterampilan dan sikap pada konteks yang tepat.

Kompetensi Guru SMK di Indonesia tertuang dalam Peraturan Pemerintah No. 19 Tahun 2005 tentang Standar Nasional Pendidikan pasal 28 ayat (3) menyatakan bahwa kompetensi yang harus dimiliki oleh seorang guru adalah sebagai berikut: (1) kompetensi pedagogik, yaitu kemampuan mengelola pembelajaran peserta didik meliputi pemahaman terhadap peserta didik, perancangan dan pelaksanaan pembelajaran, evaluasi hasil belajar, dan pengembangan peserta didik untuk mengaktualisasikan berbagai kompetensi yang dimilikinya; (2) kompetensi kepribadian, yaitu kemampuan kepribadian yang mantap, stabil, dewasa, arif dan berwibawa, menjadi teladan bagi peserta didik, dan berakhlak mulia; (3) kompetensi professional, yaitu kemampuan penguasaan materi pembelajaran secara luas dan mendalam yang memungkinkannya membimbing peserta didik memenuhi standar kompetensi yang ditetapkan; dan (4) kompetensi sosial, yaitu kemampuan pendidik sebagai bagian dari masyarakat untuk berkomunikasi dan bergaul secara efektif dengan peserta didik, sesama pendidik, tenaga kependidikan, orang tua/wali peserta didik, dan masyarakat sekitar.

Dalam rangka mencapai peningkatan jumlah guru produktif SMK yang professional tersebut Direktorat Pembinaan Pendidik dan Tenaga Kependidikan Pendidikan Menengah 
Tabel 1. Sejarah Program

\begin{tabular}{cclc}
\hline No & Tahun & \multicolumn{1}{c}{ Nama Program } & $\begin{array}{c}\text { Jumlah PT } \\
\text { Pelaksana }\end{array}$ \\
\hline 1. & 2008 & Program Pendampingan SMK & 8 PT \\
2. & 2009 & Program Pendampingan SMK & 10 PT \\
3. & 2010 & Program Pendampingan Penyelenggaraan Pendidikan Kejuruan & 13 PT \\
4. & 2011 & Program Peningkatan Profesionalisme Tenaga Pengajar Berbasis TIK & 20 PT \\
& & dengan Pola Pendampingan & 15 PT \\
5. & 2012 & Program Pendampingan SMK & 10 PT \\
6. & 2013 & Program Talent Scouting Guru SMK & \\
\hline
\end{tabular}

(P2TK Dikmen Kemdikbud) bekerjasama dengan perguruan tinggi pelaksana program telah menyelenggarakan Program Talent Scouting Guru SMK dalam rangka membantu pemenuhan guru produktif di SMK yang masih berstatus sebagai Unit Sekolah Baru (USB). Program Talent Scouting Guru SMK adalah program perbantuan yang dilakukan oleh Lembaga/Institusi Pendidikan Tinggi yang memiliki pengalaman dan kompetensi untuk memberikan bimbingan dan layanan dalam bidang peningkatan SDM SMK, peningkatan mutu pembelajaran, pengembangan inovasi dan perangkat pembelajaran, membangun sumber belajar, membantu kegiatan ekstrakurikuler dan penataan administrasi sekolah (Direktorat P2TK Dikmen Kemdikbud, 2013, p.12).

Program Talent Scouting Guru SMK ini dimulai pada tahun 2008 sampai saat ini yaitu tahun 2013. Program ini dilaksanakan bekerjasama dengan berbagai Perguruan Tinggi yang tersebar di wilayah Indonesia sebagai pelaksana Program Talent Scouting Guru SMK. Dari tahun ke tahun program ini telah mengalami beberapa perubahan nama dan jumlah Perguruan Tinggi pelaksana yang berbeda-beda yang dapat dilihat pada tabel 1 .

Pada tahun 2013 program ini dilaksanakan oleh Direktorat P2TK Dikmen Kemdikbud bekerjasama dengan 10 (sepuluh) Perguruan Tinggi yang memiliki kompetensi dan pengalaman yang tersebar di wilayah Indonesia sebagai pelaksana program. Kesepuluh perguruan tinggi tersebut adalah: FT UNIMED, FT UNP, FPTK UPI, FT UNNES, FT UNY, JPTK-FKIP UNS, FT UNESA, FT UM, FT UNM, dan FT UNIMA.

Tujuan Program Talent Scouting Guru SMK adalah: (1) tersedianya tenaga pendidik (guru) untuk mengajar sesuai dengan program keahlian di SMK yang ditunjuk; (2) kegiatan belajar mengajar dapat berjalan dengan baik; (3) adanya program penataan lingkungan sekolah yang sehat; (4) adanya program administrasi sekolah; (5) adanya program penataan perpustakaan sekolah; (5) adanya program penataan laboraturium sekolah; dan (7) terbantunya kegiatan ekstrakurikuler di sekolah.

Komponen dan kriteria keberhasilan Program Talent Scouting Guru SMK meliputi adanya relevansi program dengan pihak terkait (Direktorat P2TK Dikmen Kemdikbud, perguruan tinggi, dan SMK), adanya input penyelenggara program, input peserta program, dan input SMK sasaran program, adanya proses sosialisasi, seleksi dan pembekalan program, proses pelaksanaan program, proses monitoring dan pelaporan program, serta adanya produk teaching dan non teaching.

Berdasarkan hasil observasi dan analisis data awal terhadap laporan akhir pelaksanaan Program Talent Scouting Guru SMK tahun 2012, ditemukan banyak permasalahan yang ditemui di lapangan, antara lain: (1) ditemukan adanya ketidaksesuaian data di pihak Direktorat P2TK Dikmen Kemdikbud dengan data di lapangan berkaitan dengan lokasi dan program keahlian yang ada di sekolah sasaran program; (2) beberapa SMK yang didampingi ternyata merupakan SMK yang sudah baik dengan kualifikasi Sekolah Berstandar Internasional (SBI) dan Rintisan Sekolah Berstandar Internasional (RSBI), di mana seharusnya sekolah yang menjadi sasaran program adalah sekolah yang masih berstatus USB; (3) banyak sekolah belum mengetahui adanya Program Talent Scouting Guru SMK, hal ini menunjukan kurangnya koordinasi 
dan sosialisasi yang baik antar pihak-pihak yang terlibat di dalam pelaksanaan program; (4) banyak peserta yang tidak melewati proses seleksi Program Talent Scouting Guru SMK, hal ini menunjukan kurangnya adanya sistem seleksi yang baik; (5) banyak peserta yang tidak melakukan tugas Program Talent Scouting Guru SMK di sekolah sasaran, hal ini menunjukkan kurang termonitornya keberadaan peserta di lokasi SMK sasaran program; (6) belum diketahui keefektifan program Talent Scouting Guru SMK yang telah dilaksanakan terkait dengan relevansi tujuan utama; serta (7) belum diketahui ketercapaian hasil program Talent Scouting Guru SMK. Melihat permasalahan tersebut maka penulis melakukan penelitian evaluasi program terhadap pelaksanaan Program Talent Scouting Guru SMK tahun 2013 pada Direktorat P2TK Dikmen Kemdikbud dengan mengambil studi kasus pelaksanaan program di Universitas Negeri Semarang.

Tujuan penelitian ini adalah untuk mengetahui: (1) relevansi pelaksanaan Program Talent Scouting Guru SMK tahun 2013 ditinjau dari aspek konteks, (2) kesesuaian pelaksanaan Program Talent Scouting Guru SMK tahun 2013 ditinjau dari aspek input, (3) efektifitas pelaksanaan Program Talent Scouting Guru SMK tahun 2013 ditinjau dari aspek proses, dan (4) pencapaian hasil pelaksanaan Program Talent Scouting Guru SMK tahun 2013 ditinjau dari aspek produk.

\section{METODE PENELITIAN}

\section{Jenis Penelitian}

Jenis penelitian yang dipilih adalah evaluasi program, dengan rasional untuk mengetahui pelaksanaan Program Talent Scouting Guru SMK Direktorat P2TK Dikmen Kemdikbud dengan mengambil studi kasus pelaksanaan di Universitas Negeri Semarang. Pendekatan dalam penelitian ini adalah pendekatan deskriptif kuantitatif dengan analisis deskriptif untuk menilai pelaksanaan program.

\section{Tempat dan Waktu Penelitian}

Penelitian ini dilakukan di Direktorat P2TK Dikmen Kemdikbud sebagai pembuat kebijakan, di Universitas Negeri Semarang sebagai institusi pelaksana program, serta di SMK sasaran program. Waktu Penelitian ini bulan Desember 2013 - Januari 2014.

\section{Populasi dan Sampel}

Populasi dalam penelitian ini adalah peserta program, SMK sasaran program, dan pelaksana Program Talent Scouting Guru SMK seluruh Indonesia. Teknik sampling penelitian menggunakan teknik Purposive Sampling, yaitu teknik sampling yang satuan samplingnya dipilih berdasarkan pertimbangan tertentu dengan tujuan untuk memperoleh satuan sampling yang memiliki karakteristik atau kriteria yang dikehendaki dalam pengambilan sampel. Sampel dalam penelitian Program Talent Scouting Guru SMK ini adalah peserta program, SMK sasaran program, dan pelaksana Program Talent Scouting Guru SMK dibawah Perguruan Tinggi pelaksana Universitas Negeri Semarang.

SMK sasaran program yang menjadi sampel penelitian merupakan SMK sasaran program yang berada di wilayah pantura Jateng dan memiliki Program keahlian dibawah FT Unnes yaitu meliputi SMK N 1 Warung Asem Batang, SMK N 3 Kudus, SMK N 1 Kudus, SMK N 2 Slawi, SMK N 1 Petarukan, SMK N 1 Pekalongan, SMK N 1 Sayung, SMK N 1 Bawen, SMK N 1 Ampelgading, SMK N 3 Kendal, SMK N 2 Demak, dan SMK N 2 Kendal.

\section{Teknik Pengumpulan Data}

Teknik pengumpulan data yang digunakan pada penelitian ini adalah angket, wawancara dan dokumentasi. (1) Angket digunakan untuk menjaring data yang behubungan dengan Program Talent Scouting Guru SMK. Angket ditujukan kepada peserta program, Guru Pembimbing di SMK sasaran program, dan Dosen Pendamping Lapangan program. (2) Wawancara digunakan untuk mendapatkan data yang tidak terungkap melalui angket serta untuk cek dan recek data. Subyek wawancara adalah panitia dari Direktorat P2TK Dikmen Kemdikbud, Koordinator program dari Universitas Negeri Semarang, Kepala Sekolah di SMK sasaran program dan peserta program. (3) Dokumentasi digunakan untuk memperoleh bukti fisik pelaksanaan Program Talent Scouting Guru SMK. Bukti dokumentasi 
lainya adalah dokumen dan hasil laporan akhir Program yang kemudian dianalisis dan digunakan sebagai pembanding terhadap hasil angket dan wawancara.

\section{Kriteria Evaluasi}

Kriteria evaluasi konteks ditujukan untuk menilai tingkat relevansi program. Kriteria evaluasi input ditujukan untuk menilai kesesuaian input SMK sasaran program, peserta program dan pelaksana program. Kriteria evaluasi proses ditujukan untuk menilai keefektifan proses sosialisasi, seleksi dan pembekalan program, proses pelaksanaan program, serta proses monitoring dan pelaporan program. Kriteria evaluasi produk ditujukan untuk menilai pencapaian hasil dari program yaitu pencapaian produk teaching dan non teaching pada SMK sasaran program.

Tabel 2. Kriteria Persentase Evaluasi

\begin{tabular}{ccc}
\hline No & $\begin{array}{c}\text { Persentase } \\
\text { pencapaian (\%) }\end{array}$ & Interpretasi \\
\hline 1 & $81-100$ & Sangat baik \\
2 & $66-80$ & Baik \\
3 & $51-65$ & Cukup baik \\
4 & $36-50$ & Kurang baik \\
5 & $\leq 35$ & Tidak baik \\
\hline
\end{tabular}

\section{Teknik Analisis Data}

Teknik analisis data yang digunakan adalah analisis deskriptif kuantitatif dengan tujuan untuk melihat evaluasi program. Dalam analisis deskriptif kuantitatif data yang diolah berdasar analisis data angket yang dikumpulkan dan dianalisis dengan metode persentase. Dari penyajian data dalam bentuk persentase selanjutnya dideskripsikan dan diambil kesimpulan dari masing-masing komponen dan indikator berdasarkan kriteria yang ditentukan.
Besarnya persentase adalah hasil analisis data yang menunjukkan pada kategori yang telah ditentukan pada kriteria penilaian program. Dengan perhitungan persentase yang diungkapkan berdasar komponen-komponen yang didapatkan dan didukung dari data dan informasi melalui wawancara dan dokumentasi maka akan disimpulkan bagaimana pelaksanaan program yang telah dievaluasi. Selanjutnya hasil akhir dari evaluasi program digunakan dalam rangka menentukan rekomendasi program.

\section{HASIL PENELITIAN DAN PEMBAHASAN}

\section{Evaluasi Aspek Konteks}

Evaluasi aspek konteks mencakup masalah yang berkaitan dengan relevansi program dengan pihak-pihak (stakeholders) yang terlibat di dalam pelaksanaan program. Pada aspek konteks ini akan dilihat sejauh mana relevansi antara tujuan Program Talent Scouting Guru SMK dengan tiga komponen yang terlibat dalam program yaitu Direktorat P2TK Dikmen Kemdikbud selaku pembuat kebijakan, perguruan tinggi pelaksana, dan Sekolah Menengah Kejuruan selaku penerima program.

Berdasarkan Tabel 3 dapat diketahui bahwa pelaksanaan Program Talent Scouting Guru SMK Tahun 2013 di UNNES ditinjau dari aspek konteks yaitu pencapaian relevansi antara tujuan Program Talent Scouting Guru SMK dengan tiga komponen yang terlibat dalam program; Direktorat P2TK Dikmen Kemdikbud selaku pembuat kebijakan, perguruan tinggi pelaksana, dan SMK selaku penerima program termasuk dalam kategori "sangat relevan" dengan persentase pencapaian $85 \%$.

Tabel 3. Nilai Pencapaian Relevansi Program

\begin{tabular}{lccccc}
\hline Responden & Jml (R) & Jml. Soal & Tot. Skor & Rata-rata & persentase (\%) \\
\hline Peserta program & 20 & 7 & 594 & 29,7 & $84,86 \%$ (sangat relevan) \\
Guru pembimbing & 20 & 7 & 572 & 28,6 & $81,71 \%$ (sangat relevan) \\
Dosen pendamping & 20 & 7 & 619 & 30,9 & $88,43 \%$ (sangat relevan) \\
\hline \multicolumn{7}{l}{ Total rata-rata persentase pencapaian } \\
\hline
\end{tabular}


Tabel 4. Nilai Kesesuaian SMK Sasaran

\begin{tabular}{lccccc}
\hline Responden & Jml (R) & Jml. Soal & Tot. Skor & Rata-rata & persentase (\%) \\
\hline Peserta program & 20 & 3 & 236 & 11,8 & $78,6 \%$ (sesuai) \\
Guru pembimbing & 20 & 3 & 240 & 12 & $80 \%$ (sesuai) \\
Dosen pendamping & 20 & 3 & 237 & 11,8 & $79 \%$ (sesuai) \\
\hline \multicolumn{7}{l}{ Total rata-rata persentase pencapaian } \\
\hline
\end{tabular}

Direktorat P2TK Dikmen Kemdikbud mempunyai tugas melaksanakan perumusan dan koordinasi pelaksanaan kebijakan serta fasilitasi penerapan standar teknis di bidang pendidik dan tenaga kependidikan pendidikan menengah. Berbagai kegiatan telah dilakukan dalam rangka melaksanakan program pemerataan dan perluasan akses pendidikan menengah. Berdasarkan wawancara dengan pihak Direktorat P2TK Dikmen Kemdikbud dapat diketahui bahwa Program Talent Scouting Guru SMK bertujuan untuk membantu proses kegiatan belajar mengajar di sekolah-sekolah yang masih membutuhkan guru produktif dimana hal ini sejalan dengan tujuan Direktorat P2TK Dikmen Kemdikbud dalam rangka pemenuhan jumlah dan mutu guru di Sekolah Menengah Kejuruan.

Berdasarkan wawancara dan observasi lapangan di Universitas Negeri Semarang menyebutkan bahwa pelaksanaan Program Talent Scouting Guru SMK sejalan dengan pelaksanaan tri darma perguruan tinggi di bidang pengabdian masyarakat yaitu berupa penerapan ilmu pengetahuan dan teknologi (iptek) tepat guna, meningkatkan kerja sama perguruan tinggi untuk mendukung pengembangan industri kecil daerah/nasional serta meningkatkan partisipasi perguruan tinggi dalam pembangunan masyarakat. Oleh sebab itu, dapat dikatakan bahwa ada relevansi antara tujuan Program Talent Scouting Guru SMK dengan tujuan dari perguruan tinggi pelaksana program.

Kemudian untuk mendapatkan informasi dan data secara langsung mengenai relevansi program dengan SMK sasaran program, dilakukan kunjungan ke sekolah yang menjadi sasaran program untuk melakukan wawancara dan pengamatan. Berdasarkan hasil wawancara menunjukan adanya relevansi antara tujuan Program Talent Scouting Guru SMK dengan tujuan yang ada disekolah. Tujuan dan misi yang ada di sekolah akan bisa tercapai jika di sekolah tersedia guru produktif yang mencukupi dan kompeten serta mengajar sesuai dengan program studi yang dimilikinya. Oleh karena itu, dapat disimpulkan bahwa ada relevansi antara tujuan Program Talent Scouting Guru SMK dengan tujuan yang ingin dicapai oleh pihak sekolah.

Dari pembahasan secara umum di atas, dilihat dari aspek konteks menunjukan adanya relevansi antara tujuan Program Talent Scouting Guru SMK dengan tujuan yang ada di Direktorat P2TK Dikmen Kemdikbud selaku pembuat kebijakan, Universitas Negeri Semarang selaku perguruan tinggi pelaksana, dan di SMK selaku penerima program.

\section{Evaluasi Aspek Input}

Evaluasi input SMK sasaran program dinilai dari kesesuaian SMK dengan kriteria SMK sasaran dalam mengikuti Program Talent Scouting Guru SMK. Kriteria tersebut adalah: (a) merupakan sekolah negeri; (b) masih kekurangan tenaga pendidik bidang produktif; (c) merupakan Unit Sekolah Baru (USB) tahun 2005 dan setelahnya.

Berdasarkan Tabel 4 dapat diketahui bahwa kesesuaian input SMK sasaran pada Program Talent Scouting Guru SMK di UNNES termasuk dalam kategori "sesuai" dengan persentase pencapaian sebesar 79,22\%.

Kemudian untuk memperoleh informasi dan data berkaitan dengan SMK sasaran program, peneliti juga melakukan wawancara dengan pihak Direktorat P2TK Dikmen Kemdikbud, pihak UNNES dan pihak sekolah. selain itu juga melakukan studi dokumen terhadap laporan akhir (final report) peserta program.

Berdasarkan wawancara, observasi dan studi dokumen, terdapat 12 sekolah yang di- 
Tabel 5. Nilai Kesesuaian Peserta Program

\begin{tabular}{lccccc}
\hline \multicolumn{1}{c}{ Responden } & $\begin{array}{c}\text { Jml } \\
(\mathbf{R})\end{array}$ & Jml. Soal & Tot. Skor & $\begin{array}{c}\text { Rata- } \\
\text { rata }\end{array}$ & Persentase (\%) \\
\hline Peserta program & 20 & 3 & 249 & 12,4 & $83 \%$ (sesuai) \\
Guru pembimbing & 20 & 3 & 224 & 11,2 & $74,66 \%$ (sesuai) \\
Dosen pendamping & 20 & 3 & 239 & 11,9 & $79,66 \%$ (sesuai) \\
\hline \multicolumn{7}{l}{ Total rata-rata persentase pencapaian } \\
\hline
\end{tabular}

dampingi oleh pihak UNNES yang dijadikan sampel penelitian. Dari ke-12 sekolah tersebut semuanya merupakan sekolah negeri, kemudian dari sisi tahun berdirinya yaitu USB yang berdiri tahun 2005 dan setelahnya, hanya SMK N 1 Kudus yang telah berdiri pada tahun 1968 . Namun demikian sekolah tersebut masih membutuhkan guru produktif.

Dalam penentuan sekolah yang didampingi dibatasi pada USB yang berdiri tahun 2005 dan setelahnya karena sekolah-sekolah tersebut masih sangat membutuhkan bantuan termasuk untuk keterpenuhan tenaga pendidik sesuai program keahlian yang dibuka. Didalam menentukan sekolah serta program keahlian yang dibuka pihak Direktorat P2TK Dikmen Kemdikbud mengacu kepada kondisi data pokok SMK yang ada. Data pokok yang menampilkan kondisi sekolah SMK di seluruh Indonesia bisa diakses di website www.datapokok.ditpsmk.net. Data tersebut sudah cukup lengkap, namun permasalahan yang terjadi adalah pada sinkronisasi data dimana pada realisasinya banyak terjadi ketidaksesuaian antara data pokok SMK dengan data yang ada di lapangan. Hal ini terjadi karena cepatnya perubahan data yang ada di lapangan dan belum terdata di data pokok SMK terutama berkaitan dengan kondisi jumlah siswa dan kondisi kebutuhan tenaga pendidik.

Melihat kondisi ini kedepan sebaiknya harus ada crosscheck data ke sekolah yang akan didampingi dan memastikan kebenaran data yang ada sehingga tidak terjadi lagi ketidaksesuaian data baik data sekolah maupun data program keahlian yang dibutuhkan. Ketidaksesuaian data antara data yang ada di pihak Direktorat P2TK Dikmen Kemdikbud dengan data dilapangan bisa diatasi dengan memberikan kesempatan kepada Perguruan Tinggi pelaksana untuk melakukan observasi awal terhadap sekolah-sekolah yang akan menjadi sasaran program sehingga sehingga data yang ada benar-benar sesuai.

Secara umum pada komponen SMK sasaran telah memenuhi kriteria yang ditetapkan pada indikator keberhasilan program namun ke depan harus lebih ditingkatkan lagi berkaitan dengan kesesuaian data di pihak Direktorat P2TK Dikmen Kemdikbud dengan data yang ada di sekolah sehingga keberadaan peserta Talent Scouting di sekolah yang didampingi bisa lebih optimal karena adanya kesesuaian kebutuhan tenaga pendidik bidang produktif di sekolah dengan program studi yang dimiliki oleh peserta.

Evaluasi input peserta program dinilai dari kesesuaian peserta dengan kriteria peserta dalam mengikuti Program Talent Scouting Guru SMK. Kriteria tersebut adalah: (a) telah menempuh minimal $110 \mathrm{SKS}$; (b) program studi sesuai dengan program keahlian yang dibutuhkan SMK sasaran; dan (c) telah lulus mata kuliah pengajaran microteaching atau yang ekuivalen.

Berdasarkan Tabel 5 dapat diketahui bahwa kesesuaian input peserta program pada pelaksanaan Program Talent Scouting Guru SMK Tahun 2013 di UNNES termasuk dalam kategori "sesuai" dengan persentase pencapaian sebesar 79,11\%.

Selanjutnya untuk menguatkan data angket tersebut dilakukan analisa dokumen laporan pelaksanaan program serta melakukan wawancara langsung ke pihak perguruan tinggi, peserta maupun ke pihak sekolah. Berdasarkan wawancara dan analisa dokumen diperoleh data bahwa dari 20 peserta ada 2 peserta yang kurang sesuai antara program studi yang dimiliki dengan program keahlian yang dibutuhkan di sekolah, yaitu TA dimana 
Tabel 6. Nilai Kesesuaian Penyelenggara

\begin{tabular}{llllll}
\hline Responden & $\begin{array}{c}\text { Jml } \\
(\mathbf{R})\end{array}$ & Jml. Soal & Tot.Skor & $\begin{array}{c}\text { Rata- } \\
\text { rata }\end{array}$ & \multicolumn{1}{c}{ Persentase (\%) } \\
\hline Peserta program & 20 & 12 & 808 & 40,4 & $67,33 \%$ (sesuai) \\
Guru pembimbing & 20 & 12 & 847 & 42,4 & $70,58 \%$ (sesuai) \\
Dosen pendamping & 20 & 12 & 894 & 44,7 & $74,5 \%$ (sesuai) \\
\hline \multicolumn{7}{l}{ Total rata-rata persentase pencapaian } \\
\hline
\end{tabular}

program studi S1 adalah Pendidikan Tata Boga, sedangkan pada penempatan di SMK N 2 Slawi peserta mengajar pada bidang keahlian Agribisnis Hasil Pertanian. Peserta yang kedua adalah CM, Program Studi S1 adalah Pendidikan Biologi yang juga mengajar pada Program Keahlian Agribisnis Hasil Pertanian di SMK N 1 Bawen. Namun demikian, meskipun jurusan yang didampingi di sekolah tidak satu program studi tetapi masih dalam satu rumpun. Hal ini disebabkan karena di UNNES tidak memiliki program studi Pertanian, maka UNNES mengambil peserta dari program studi yang serumpun yaitu Biologi dan Tata Boga.

Disamping harus memiliki kesesuaian antara program studi yang dimiliki dengan program keahlian yang diajarkan di SMK seorang guru kejuruan juga harus memiliki kompetensi yang harus dipenuhi. Berdasarkan permendiknas Nomor 16 Tahun 2007 tentang standar kualifikasi akademik dan Kompetensi Guru SMK di Indonesia yang tertuang dalam Peraturan Pemerintah No. 19 Tahun 2005 tentang Standar Nasional Pendidikan pasal 28 ayat (3) menyatakan bahwa seorang guru di SMK harus memiliki 4 kompetensi yaitu kompetensi pedagogik, kompetensi kerpribadian, kompetensi professional, dan kompetensi sosial.

Dari temuan dilapangan berdasarkan laporan pihak sekolah menunjukan bahwa ternyata masih ada peserta yang masih mengambil SKS sehingga hal ini mengganggu pelaksanaan program di sekolah sasaran sebab peserta terkadang harus meminta ijin ke sekolah untuk mengikuti kuliah di kampus sehingga keberadaan peserta di SMK tidak optimal. Kemudian juga ada peserta yang kurang kompeten dalam mengajar di kelas sehingga hal ini menjadi masukan bagi institusi pelaksana agar lebih ketat di dalam melakukan seleksi sehingga memang peserta yang kompeten dan professional yang mengikuti program baik dari sisi kesesuaian program studi maupun kemampuan mengajar.

Agar kegiatan KBM dapat terlaksana dengan efektif dan efisien yang bermuara pada penciptaan lulusan yang bermutu, keberadaan guru yang kompeten mempunyai peran yang sangat menentukan dan merupakan kunci keberhasilan. Oleh karena itu hal ini perlu menjadi perhatian yang serius bagi LPTK (Lembaga Pendidikan Tenaga Kependidikan) sebagai penghasil guru termasuk dalam Program Talent Scouting Guru SMK yang dijalankan agar bisa selektif dalam memilih peserta sehinggga benar-benar memiliki kompetensi yang memadai.

Kemudian berkaitan dengan indikator kesediaan peserta untuk ditempatkan di sekolah sasaran, telah dilakukan studi dokumen. Berdasarkan studi dokumen yang ada, setiap peserta program telah diminta untuk menandatangani form kesediaan untuk ditempatkan di sekolah yang nantinya akan ditetapkan oleh Direktorat P2TK Dikmen Kemdikbud serta bersedia menjalankan tugas dengan sebaik-baiknya.

Evaluasi input penyelenggara program dinilai dari kesesuaian penyelenggara dengan kriteria dalam mengikuti Program Talent Scouting Guru SMK. Kriteria tersebut adalah: (a) adanya Panlak/KAK; (b) adanya tim pelaksana pada LPTK; (c) memiliki program studi sesuai dengan program keahlian yang dibutuhkan di sekolah menengah kejuruan; (d) adanya sarana dan prasarana yang memadai; serta (e) adanya interaksi dan komunikasi yang baik antar penyelenggara program.

Berdasarkan Tabel 6 dapat diketahui bahwa kesesuaian input penyelenggara program pada pelaksanaan Program Talent 
Scouting Guru SMK Tahun 2013 di UNNES termasuk dalam kategori "sesuai" dengan persentase pencapaian sebesar $70,8 \%$.

Salah satu komponen input dalam penyelenggara Program Talent Scouting Guru SMK adalah adanya panduan pelaksanaan. Panduan pelaksanaan dibuat sebagai pedoman didalam pelaksanaan program dan agar stakeholders memiliki pemahaman yang sama terhadap program yang dijalankan. Panduan pelaksanaan ada 2 jenis yaitu yang dibuat oleh pihak Direktorat P2TK sebagai pedoman bagi LPTK serta panduan pelaksanaan yang dibuat oleh pihak UNNES sebagai pedoman bagi peserta dan SMK.

Berdasarkan analisa dokumen dan wawancara dengan informan berkaitan dengan buku panduan pelaksanaan/KAK yang dibuat oleh pihak Direktorat P2TK Dikmen Kemdikbud dan pihak perguruan tinggi pelaksana, secara umum dapat dikatakan bahwa untuk panlak/ KAK dalam pelaksanaan Program Talent Souting Guru SMK telah cukup memenuhi indikator keberhasilan yang ditetapkan.

Indikatorselanjutnyapadainputpenyelenggara program adalah adanya tim pelaksana program. Berdasarkan studi dokumen yang ada pada Program Talent Scouting Guru SMK yang dilaksanakan oleh UNNES, menjelaskan bahwa susunan dari tim pelaksana program mulai penanggung jawab yaitu Dekan FT, wakil penanggung jawab 1 sampai 3 yaitu pembantu dekan 1 sampai 3, kemudian ketua pelaksana/ koordinator, sekretaris, bendahara serta seksiseksi yang ada. Dari susunan pelaksana yang ada menunjukan adanya tim pelaksana tugas yang cukup lengkap namun dari sisi pembagian tugas tidak disebutkan secara rinci hanya global saja sehingga ke depan perlu diperinci tugas dan tanggung jawabnya agar lebih jelas sehingga akan lebih memudahkan suatu organisasi dalam melaksanakan tujuannya.

Indikator ketiga dari kesesuaian input penyelenggara program adalah memiliki program studi sesuai dengan program keahlian yang dibutuhkan di SMK. Dari hasil wawancara dengan pihak pengelola, menjelaskan bahwa secara umum ada kesesuaian antara program studi yang dimiliki oleh UNNES dengan kebutuhan guru produktif di SMK yang didam- pingi. Hanya saja untuk bidang keahlian Agribisnis Hasil Pertanian karena di UNNES tidak ada program studi pertanian, maka peserta diambilkan dari Program Studi Jasa Boga dan Biologi. Maka dari itu, pada saat pembekalan telah dilakukan tambahan materi oleh pihak UNNES sehingga diharapkan peserta tersebut memiliki bekal untuk mengajar di sekolah serta memiliki kompetensi di dalam pengelolaan pembelajaran di sekolah.

Indikator kinerja selanjutnya adalah adanya sarana dan prasarana yang memadai. Dari hasil wawancara dan pengamatan dilapangan menunjukan bahwa seluruh sarana prasarana yang dibutuhkan untuk pelaksanaan program sudah dapat dipenuhi dan memadai. Ruang sekretariat memiliki fasilitas yang cukup memadai dengan adanya ruang tamu, ruang sekretariat yang dilengkapi meja, kursi, komputer yang terkoneksi internet, printer, mesin foto copy dan juga telepon. Ketersediaan sarana dan prasarana yang memadai merupakan salah satu komponen penting agar pelaksanaan program bisa tercapai. Oleh karena itu dalam penyedian sarana dan prasarana harus sesuai dengan prinsip kecukupan, relevansi dan daya guna.

\section{Evaluasi Aspek Proses}

Evaluasi proses sosialisasi, seleksi dan pembekalan program dinilai dari keefektifan tiap indikator yang ditentukan dalam mengikuti Program Talent Scouting Guru SMK. Indikator tersebut adalah: (a) proses sosialisasi yang dilakukan oleh pihak Direktorat P2TK Dikmen Kemdikbud; (b) proses sosialisasi yang dilakukan oleh pihak Universitas Negeri Semarang kepada calon peserta; (c) proses seleksi dan penetapan; dan (d) proses pembekalan dari penyelenggara program.

Berdasarkan Tabel 7 dapat diketahui bahwa keefektifan proses sosialisasi, seleksi dan pembekalan pada Program Talent Scouting Guru SMK Tahun 2013 di UNNES termasuk dalam kategori "efektif" dengan persentase pencapaian $66,42 \%$.

Berdasarkan studi dokumen didapatkan data bahwa Direktorat P2TK Dikmen Kemdikbud pada tahun 2012 telah melaksanakan sosialisasi program pada awal tahun anggaran 
Tabel 7. Nilai Keefektifan Proses Sosialisasi, Seleksi dan Pembekalan

\begin{tabular}{lccccc}
\hline Responden & $\begin{array}{c}\text { Jml } \\
(\mathbf{R})\end{array}$ & Jml. Soal & Tot. Skor & $\begin{array}{c}\text { Rata- } \\
\text { rata }\end{array}$ & Persentase(\%) \\
\hline Peserta program & 20 & 9 & 270 & 13,5 & $67,5 \%$ (efektif) \\
Guru pembimbing & 20 & 9 & 235 & 11,8 & $58,75 \%$ (efektif) \\
Dosen pendamping & 20 & 9 & 292 & 14,6 & $73 \%$ (efektif) \\
\hline \multicolumn{7}{l}{ Total rata-rata persentase pencapaian }
\end{tabular}

dengan melaksanakan rapat koordinasi program tingkat nasional dengan mengundang perwakilan dari dinas pendidikan provinsi dan kabupaten/kota di seluruh Indonesia. Pada kegiatan tersebut dipaparkan program-program yang akan dijalankan oleh Direktorat P2TK Dikmen Kemdikbud termasuk didalamnya Program Talent Scouting Guru SMK. Kemudian dari kegiatan tersebut ditindaklanjuti dengan kegiatan rapat koordinasi tingkat provinsi yang diadakan oleh masing-masing provinsi.

Proses sosialisasi yang dilakukan oleh UNNES dilakukan untuk menjaring peserta yang berminat untuk mengikuti Program Talent Scouting Guru SMK. Untuk dapat menjaring peserta secara optimal sehingga diperoleh peserta yang kompeten dan profesional hendaknya sosialisasi dilakukan melalui berbagai cara, diantaranya: memasang spanduk di kampus, melalui pemberitaan surat resmi ke berbagai fakultas, melalui media massa, melalui internet, secara pendekatan informal, serta pembuatan leaflet yang dipasang di tempat strategis sehingga diharapkan bisa diketahui oleh calon peserta. Sosialisasi merupakan hal yang penting dimana dengan sosialisasi yang maksimal maka diharapkan pihak-pihak yang terlibat bisa mengetahui serta memiliki pemahaman yang sama terhadap suatu program.

Selanjutnya proses seleksi yang dilakukan oleh Direktorat P2TK Dikmen Kemdikbud kepada calon Institusi pelaksana dilakukan dengan melihat kepada kinerja yang telah dilakukan oleh perguruan tinggi yang telah melaksanakan pada tahun sebelumnya. Halhal yang dilihat adalah kompetensi, kapasitas dan kinerja, meliputi keterpenuhan sasaran, kesesuaian laporan baik dari isi dan waktu, penggunaan dana serta pemaparan pada saat laporan akhir. Kemudian pihak Direktorat P2TK Dikmen Kemdikbud membuat tim evaluasi, dimana tim inilah yang akan me- lakukan evaluasi secara menyeluruh kemudian melaporkan hasilnya kepada penyelenggara. Kemudian untuk penetapan sekolah yang didampingi berasal dari data pokok SMK, informasi langsung dari pihak sekolah serta informasi dari pelaksanaan tahun sebelumnya.

Komponen berikutnya berkaitan dengan aspek proses adalah kegiatan pembekalan yang dilakukan oleh pihak UNNES. Kegiatan pembekalan merupakan kegiatan yang dilaksanakan oleh pihak perguruan tinggi pelaksana kepada peserta sebelum diterjunkan ke sekolah. Indikator kinerja yang dilihat adalah pihak pelaksana dalam hal ini perguruan tinggi melaksanakan pembekalan dan materi yang disampaikan sudah mencakup kebijakan program Direktorat P2TK Dikmen Kemdikbud serta materi manajemen sekolah. Berdasarkan studi dokumen berupa laporan yang ada, kegiatan pembekalan program Talent Scouting Guru SMK tahun 2013 dilaksanakan oleh pihak UNNES pada tanggal 22 s.d. 24 Juli 2013 di Hotel Pandanaran Semarang. Materi pembekalan antara lain: Program Talent Scouting Guru SMK, RPP, silabus Kurikulum SMK, media pembelajaran, evaluasi hasil belajar, strategi pembelajaran, perangkat pembelajaran, serta peer teaching.

Evaluasi proses pelaksanaan program dinilai dari keefektifan tiap indikator yang ditentukan dalam mengikuti Program Talent Scouting Guru SMK. Indikator tersebut adalah: (a) menyusun perangkat pembelajaran; (b) melaksanakan praktik mengajar mata diklat produktif sesuai dengan program keahlian yang ada di SMK; (c) melaksanakan evaluasi formatif terhadap proses belajar mengajar; (d) melaksanakan evaluasi sumatif terhadap proses belajar mengajar; (e) melakukan penataan sistem administrasi sekolah, melakukan pembenahan dan penataan perpusakaan sekolah; (f) melakukan pembenahan dan 
Tabel 8. Nilai Keefektifan Proses Pelaksanaan

\begin{tabular}{llllll}
\hline \multicolumn{1}{c}{ Responden } & $\begin{array}{c}\text { Jml } \\
(\mathbf{R})\end{array}$ & Jml. Soal & $\begin{array}{c}\text { Tot. } \\
\text { Skor }\end{array}$ & $\begin{array}{c}\text { Rata- } \\
\text { rata }\end{array}$ & Persentase(\%) \\
\hline Peserta program & 20 & 4 & 743 & 37.2 & $82,55 \%$ (sangat efektif) \\
Guru pembimbing & 20 & 4 & 725 & 36.3 & $80,55 \%$ (sangat efektif) \\
Dosen pendamping & 20 & 4 & 741 & 37.1 & $82,33 \%$ (sangat efektif) \\
\hline \multicolumn{7}{l}{ Total rata-rata persentase pencapaian } \\
\hline
\end{tabular}

Tabel 9. Nilai Keefektifan Proses Monitoring dan Pelaporan

\begin{tabular}{|c|c|c|c|c|c|}
\hline Responden & $\begin{array}{l}\text { Jml } \\
\text { (R) }\end{array}$ & Jml. Soal & Tot. Skor & $\begin{array}{c}\text { Rata- } \\
\text { rata }\end{array}$ & Persentase $(\%)$ \\
\hline Peserta program & 20 & 3 & 220 & 11 & $73,33 \%$ (efektif) \\
\hline Guru pembimbing & 20 & 3 & 201 & 10,1 & $67 \%$ (efektif) \\
\hline Dosen pendamping & 20 & 3 & 257 & 12,9 & $85,66 \%$ (sangat efektif) \\
\hline \multicolumn{5}{|c|}{ Total rata-rata persentase pencapaian } & $75,33 \%$ (Efektif) \\
\hline
\end{tabular}

penataan Laboraturium praktik di sekolah; (g) melakukan penataan lingkungan sekolah yang sehat dan bersih; serta (h) mengembangkan kegiatan ekstra kurikuler sekolah dan tugas lain yang relevan.

Berdasarkan Tabel 8 dapat diketahui bahwa keefektifan proses pelaksanaan Program Talent Scouting Guru SMK Tahun 2013 di UNNES termasuk dalam kategori "sangat efektif" dengan persentase pencapaian $81,81 \%$.

Pada proses pelaksanaan program, tugas peserta program adalah: menyusun perangkat pembelajaran, melaksanakan praktik mengajar mata diklat produktif, melaksanakan evaluasi formatif dan sumatif terhadap proses belajar mengajar, melakukan penataan sistem administrasi sekolah, melakukan pembenahan dan penataan perpusakaan sekolah, melakukan pembenahan dan penataan laboraturium praktik di sekolah, melakukan penataan lingkungan sekolah yang sehat dan bersih, serta mengembangkan kegiatan ekstra kurikuler sekolah dan tugas lain yang relevan.

Berdasarkan wawancara dan studi dokumen yang ada terhadap laporan akhir peserta menunjukan bahwa semua peserta telah membantu proses proses pelaksanaan program di SMK sasaran dengan baik. Hal ini menunjukkan bahwa keefektifan proses pelaksanaan program telah memenuhi indikator keberhasilan program yang ditetapkan.
Evaluasi proses monitoring dan pelaporan dinilai dari keefektifan tiap indikator yang ditentukan dalam mengikuti Program Talent Scouting Guru SMK. Indikator tersebut adalah: (a) monitoring peserta dari Direktorat P2TK Dikmen Kemdikbud di lokasi SMK sasaran; (b) monitoring peserta dari Unnes di lokasi SMK sasaran dan (c) proses pelaporan hasil program.

Berdasarkan Tabel 9 dapat diketahui bahwa keefektifan proses monitoring dan pelaporan pada Program Talent Scouting Guru SMK di UNNES termasuk dalam kategori "efektif" dengan persentase pencapaian $75,33 \%$.

Tujuan monitoring adalah untuk memantau pelaksanaan Program Talent Souting Guru SMK di lapangan apakah sudah berjalan sebagaimana mestinya kemudian juga mengambil solusi dan penyelesaian terhadap masalah yang terjadi di lapangan. Berdasarkan studi dokumen yang ada, pihak UNNES membagi lokasi SMK yang akan di monitoring dan membagi petugas monitoring yang terlibat. Setiap petugas monitoring dilengkapi dengan: buku panduan yang berisi antara lain mekanisme dan lokasi sekolah yang akan dimonitoring, kemudian juga dilengkapi dengan surat tugas yang ditandatangani oleh dekan, serta lembar penilaian monitoring yang merupakan instrumen yang digunakan oleh 
Tabel 10. Nilai Pencapaian Produk Teaching

\begin{tabular}{|c|c|c|c|c|c|}
\hline Responden & $\begin{array}{l}\text { Jml } \\
\text { (R) }\end{array}$ & Jml. Soal & Tot. Skor & $\begin{array}{c}\text { Rata- } \\
\text { rata }\end{array}$ & Persentase $(\%)$ \\
\hline Peserta program & 20 & 3 & 257 & 12,9 & $85,66 \%$ (sangat efektif) \\
\hline Guru pembimbing & 20 & 3 & 256 & 12,8 & $85,33 \%$ (sangat efektif) \\
\hline Dosen pendamping & 20 & 3 & 258 & 12,9 & $86 \%$ (sangat efektif) \\
\hline \multicolumn{5}{|c|}{ Total rata-rata persentase pencapaian } & $85,66 \%$ (Sangat efektif) \\
\hline
\end{tabular}

dosen pendamping untuk menilai kinerja dari peserta selama berada di sekolah. Lembar penilaian ini terdiri dari aspek: teaching, nonteaching serta faktor pendukung.

Tugas seorang supervisor yaitu mengadakan komunikasi dengan peserta, mencatat perkembangan peserta, mengadakan pertemuan, dan melakukan observasi ke SMK yang didampingi. Pada saat dilakukan proses monitoring setiap peserta harus menyampaikan laporan kepada petugas supervisor dimana laporan tersebut nantinya akan dikompilasi oleh perguruan tinggi pelaksana sebagai laporan kemajuan. Kemudian berdasarkan studi dokumen didapatkan informasi bahwa untuk mengatasi lokasi-lokasi yang tidak dapat dijangkau, pihak UNNES mengembangkan pelaporan online. Sehingga bagi peserta yang lokasinya tidak bisa dilakukan monitoring bisa menyampaikan laporan dengan mengirimkan data dan foto-foto dokumentasi ke pihak Universitas. Mekanisme pelaporan via online ini cukup efektif untuk mengatasi kendala lokasi yang tidak bisa terjangkau.

Komponen aspek proses selanjutnya adalah pelaporan. Pada prinsipnya laporan pelaksanaan program yang dibuat oleh institusi harus dapat menyajikan data dan memberikan informasi yang lengkap dan jelas tentang proses persiapan, pelaksanaan, dan evaluasi sampai hasil pekerjaan dinyatakan selesai. Jenis laporan yang dibuat terdiri dari: Laporan Pendahuluan (Inception report) yang mencakup program kerja, penyusunan waktu/jadual, personal yang terlibat, lokasi pendampingan, materi, tata cara (metode) pelaksanaan pekerjaan yang digunakan dan target yang akan dicapai selama pelaksanaan pendampingan. Kemudian laporan kemajuan pekerjaan (progress report), yang menggambarkan kemajuan pekerjaan yang telah dilakukan. Kemajuan pekerjaan ha- ruslah meliputi semua komponen kinerja yang telah dicapai, laporan ini harus dibuat paling lambat 3 (tiga) bulan sejak dimulainya kegiatan atau setelah dilaksanakan monitoring. Laporan terakhir yaitu laporan akhir (final report), merupakan laporan komprehensif yang terdiri dari laporan seluruh kegiatan dilampiri dengan bukti hasil pelaksanaan pekerjaan, foto-foto dokumentasi kegiatan peserta di sekolah dan bukti penggunaan dana.

\section{Evaluasi Aspek Produk}

Pada evaluasi produk ditujukan untuk menilai pencapaian hasil dari program yaitu adanya produk teaching dan non teaching pada SMK sasaran program.

Kriteria pencapaian produk teaching meliputi: (a) adanya guru produktif yang mengajar sesuai dengan program keahlian di sekolah; (b) terbantunya proses KBM di sekolah; dan (c) adanya perangkat pembelajaran untuk membantu proses kegiatan belajar mengajar di sekolah.

Berdasarkan Tabel 10 dapat diketahui bahwa pencapaian hasil Program Talent Scouting Guru SMK Tahun 2013 di UNNES ditinjau dari aspek produk teaching termasuk dalam kategori "sangat tercapai" dengan persentase pencapaian $85,66 \%$.

Perangkat pembelajaran merupakan sekumpulan media atau sarana yang digunakan oleh guru dan siswa dalam proses pembelajaran di kelas, serangkaian perangkat pembelajaran yang harus dipersiapkan seorang guru dalam menghadapi pembelajaran di kelas diantaranya: Silabus, Rencana pelaksanaan Pembelajaran (RPP), Media pembelajaran, Buku siswa (BS), Buku Pegangan Guru (BPG), Lembar Kegiatan Siswa (LKS), dan Tes Hasil Belajar.

Sebelum seorang guru mengajar, seorang 
Tabel 11. Nilai Pencapaian Non Teaching

\begin{tabular}{|c|c|c|c|c|c|}
\hline Responden & $\begin{array}{l}\text { Jml } \\
(\mathrm{R})\end{array}$ & Jml. Soal & Tot. Skor & $\begin{array}{c}\text { Rata- } \\
\text { rata }\end{array}$ & Persentase(\%) \\
\hline Peserta program & 20 & 6 & 509 & 25,5 & $84,83 \%$ (sangat tercapai) \\
\hline Guru pembimbing & 20 & 6 & 488 & 24,4 & $81,33 \%$ (sangat tercapai) \\
\hline Dosen pendamping & 20 & 6 & 498 & 24,9 & $83 \%$ (sangat tercapai) \\
\hline \multicolumn{5}{|c|}{ Total rata-rata persentase pencapaian } & $83,05 \%$ (Sangat tercapai) \\
\hline
\end{tabular}

guru diharapkan mempersiapkan bahan yang akan diajarkan, mempersiapkan alat-alat peraga yang akan digunakan, mempersiapkan pertanyaan dan arahan untuk memancing siswa aktif belajar, mempelajari keadaan siswa, mengerti kelemahan dan kelebihan siswa, serta mempelajari pengetahuan awal siswa, kesemuanya ini akan terurai pelaksanaannya di dalam perangkat pembelajaran.

Dalam pelaksanan pembelajaran di SMK dan dalam penyusunan perangkat pembelajaran, harus disesuaikan dengan kurikulum yang dipakai. Penerapan kurikulum 2013 masih menjadi hal yang sangat baru bagi para guru di SMK sasaran. Namun dengan adanya peserta program, mampu memberikan jawaban serta informasi terkini perihal implementasi kurikulum 2013 di SMK. Hal itu dikarenakan peserta program Talent Scouting sudah diberikan materi pembekalan tentang penerapan Kurikulum 2013 di SMK. Struktur kurikulum SMK membagi kelompok mata pelajaran ke dalam 3 (tiga) kelompok, yaitu kelompok adaptif, normatif, dan produktif. Kelompok mata pelajaran produktif mempersiapkan peserta didik untuk memiliki keahlian lebih dari 121 kompetensi keahlian. Oleh karena itu, guru produktif yang mengajar harus sesuai dengan program studi guru, agar memiliki kompetensi yang memadai.

Berdasarkan Observasi dan wawancara di SMK sasaran program, menunjukkan bahwa dengan adanya Program Talent Scouting Guru SMK ini proses pembelajaran di SMK menjadi lancar dan lebih baik. Hal ini menunjukkan bahwa pencapaian hasil produk teaching sangat tercapai yaitu meliputi: guru produktif yang mengajar sesuai dengan program studi menjadi terpenuhi, terbantunya proses KBM di sekolah, dan adanya Perangkat Pembelajaran untuk membantu proses KBM di Sekolah.
Kriteria pencapaian produk non teaching meliputi: (a) adanya program penataan lingkungan sekolah yang bersih dan sehat; (b) adanya program administrasi sekolah; (c) adanya program penataan perpustakaan sekolah; (d) adanya program penataan laboraturium sekolah; serta (e) terbantunya kegiatan ekstrakurikuler di sekolah.

Berdasarkan Tabel 11 dapat diketahui bahwa pencapaian hasil Program Talent Scouting Guru SMK Tahun 2013 di UNNES ditinjau dari aspek produk non teaching termasuk dalam kategori "sangat tercapai" dengan persentase pencapaian $83,05 \%$.

Apabila melihat dari hasil pelaksanaan Program Talent Scouting Guru SMK yang telah dilakukan oleh peserta program, ternyata melalui program ini mampu memecahkan permasalahan di SMK yang masih mengalami berbagai hambatan. Dari studi dokumen terhadap laporan akhir yang dibuat oleh peserta program Talent Scouting Guru SMK, hasil produk non teaching sangat tercapai yaitu meliputi: lingkungan sekolah menjadi bersih dan sehat, administrasi sekolah menjadi lancar, perpustakaan sekolah menjadi baik, laboraturium sekolah menjadi baik, serta terbantunya kegiatan ekstrakurikuler di sekolah.

Dampak dari hasil tersebut, banyak pihak SMK yang dijadikan sasaran program, melalui perguruan tinggi mengusulkan kembali untuk mendapatkan bantuan program Talent Scouting Guru SMK di tahun berikutnya. Selain itu ada juga SMK-SMK baru yang menginginkan untuk mendapatkan program yang dilakukan oleh pihak SMK mitra. Berkenaan dengan itu tampaknya Program Talent Scouting Guru SMK yang dilakukan oleh Direktorat P2TK Dikmen Kemdikbud bekerjasama dengan perguruan tinggi pelaksana, perlu adanya perluasan wilayah SMK dan penambahan jumlah peserta program yang terlibat. 
Peserta telah melaksanakan Program Talent Scouting Guru SMK selama kurang lebih 5 bulan. Semua tanggapan dari semua peserta sangat baik terhadap program ini. Harapannya program-program kependidikan seperti ini bisa merata di seluruh negeri. Pelaksanaan Program Talent Scouting Guru SMK berjalan dengan baik karena didukung oleh berbagai pihak terutama dari pihak sekolah. Sekolah-sekolah yang didampingi dan menjadi sekolah sasaran program sangat berterimakasih dengan adanya Program Talent Scouting Guru SMK ini. Selain bertujuan untuk membantu dan memberikan manfaat kepada sekolah, program ini juga sangat bermanfaat bagi peserta agar lebih mengenal dunia pendidikan dan bersosialisasi di ranah kependidikan serta melatih bersikap sebagai tenaga pengajar yang professional. Program Talent Scouting Guru SMK ini harus terus dilaksanakan di tahun-tahun berikutnya.

\section{SIMPULAN DAN SARAN}

\section{Simpulan}

Hasil penelitian ini menunjukkan bahwa: (1) ditinjau dari aspek konteks yaitu pencapaian relevansi program termasuk dalam kategori "sangat relevan" dengan persentase pencapaian $85 \%$; (2) ditinjau dari aspek input, kesesuaian input SMK sasaran program termasuk dalam kategori "sesuai" dengan persentase pencapaian $79,22 \%$; kesesuaian input peserta program termasuk dalam kategori "sesuai" dengan persentase pencapaian 79,11\%; dan kesesuaian input penyelenggara program juga termasuk dalam kategori "sesuai" dengan persentase pencapaian 70,8\%; (3) ditinjau dari aspek proses, keefektifan proses sosialisasi, seleksi dan pembekalan termasuk dalam kategori "efektif" dengan persentase pencapaian $66,42 \%$; keefektifan proses pelaksanaan termasuk dalam kategori "sangat efektif" dengan persentase pencapaian $81,81 \%$; serta keefektifan proses monitoring dan pelaporan termasuk dalam kategori "efektif" dengan persentase pencapaian 75,33\%; dan (4) ditinjau dari aspek produk, pencapaian produk teaching termasuk dalam kategori "sangat tercapai" dengan persentase pencapaian $85,66 \%$; dan pencapaian produk non teaching termasuk dalam kategori "sangat tercapai" dengan persentase pencapaian $83,05 \%$.

Pelaksanaan Program Talent Scouting Guru SMK Tahun 2013 di Universitas Negeri Semarang secara umum sudah baik namun masih perlu diperbaiki dalam beberapa aspek agar bisa memberikan manfaat yang optimal bagi semua pihak yang terkait dengan program, yaitu meliputi peserta program, SMK sasaran program dan pelaksana program.

\section{Rekomendasi}

Rekomendasi untuk kalangan akademisi antara lain: (1) hasil penelitian ini dapat ditindaklanjuti dengan suatu penelitian yang mengarah kepada evaluasi hasil dan dampak program yang lebih lengkap sehingga diharapkan dengan tindak lanjut penelitian dapat diketahui sejauh mana tujuan program dapat tercapai dan seberapa besar tingkat kepuasan sasaran program; (2) konsep dan rumusan dari program ini perlu mendapat kajian lebih lanjut dari para pakar pendidikan dan pemangku jabatan dalam mengatasi kendala kekurangan guru khususnya untuk guru produktif di SMK.

Dari hasil penelitian ini terdapat juga beberapa rekomendasi untuk kalangan praktisi yaitu meliputi Direktorat P2TK Dikmen Kemdikbud, Perguruan Tinggi pelaksana program dan SMK sebagai penerima program.

Rekomendasi untuk Direktorat P2TK Dikmen Kemdikbud: (1) perlu adanya sosialisasi yang lebih baik terhadap program yang digulirkan baik kepada Dinas Pendidikan Kabupaten/ Kota maupun kepada SMK sehingga diharapkan akan terjalin kerjasama yang baik sehingga pelaksanaan program bisa lebih optimal; (2) periode waktu pelaksanaan hendaknya melihat kepada tahun pelajaran di sekolah yaitu pada awal tahun ajaran atau pada awal semester, sedangkan untuk perguruan tinggi idealnya dilakukan sebelum dilaksanakan program PPL dan setelah wisuda sehingga pihak perguruan tinggi relatif lebih mudah mencari peserta.

Rekomendasi untuk Perguruan Tinggi Pelaksana: (1) sosialisasi yang dilakukan untuk menjaring peserta lebih maksimal sehingga bisa mendapatkan peserta yang kompeten dan memiliki program studi yang sesuai dengan program keahlian yang dibutuhkan di sekolah; 
(2) lebih ditingkatkan lagi koordinasi dengan Dinas Pendidikan terkait dan dengan SMK sasaran berkaitan dengan kebutuhan guru produktif yang dibutuhkan; (3) materi pembekalan yang diberikan kepada peserta lebih ditingkatkan lagi baik secara kualitas maupun kuantitas sehingga peserta yang diterjunkan ke SMK memang sudah memiliki kompetensi yang cukup; (4) berkoordinasi dengan pihak Direktorat P2TK Dikmen Kemdikbud berkaitan dengan alokasi dana yang diberikan terutama untuk alokasi dana living cost bagi peserta; (5) penyampaian laporan agar tepat waktu dan sesuai dengan outline yang telah disepakati.

Rekomendasi untuk SMK sasaran program: (1) keberadaan peserta di sekolah adalah untuk membantu kegiatan sekolah maka hendaknya pihak SMK memberikan fasilitas sesuai dengan kemampuan sekolah terutama berkaitan dengan tempat menginap bagi peserta; (2) tidak memberikan beban yang berlebihan kepada peserta diluar tugas dan kemampuannya; (3) selalu berkoordinasi dengan pihak perguruan tinggi jika ada peserta yang kurang optimal kinerjanya maupun permasalahan yang lain agar segera bisa dicarikan solusi yang tepat.

\section{DAFTAR PUSTAKA}

Arikunto, Suharsimi \& Jabar, Cepi S.A. (2009). Evaluasi program pendidikan: pedoman teoritis praktis bagi mahasiswa dan praktisi pendidikan. Jakarta: Bumi Aksara.

Baraki, A.H. (2013). Effectiveness of technical and vocational education and training (TVET): insights from ethiopia's reform. The TQM Journal, 25 (5), 492-506

Beven, F. (2009). The development of training modules for instructor. Maclean, R., Wilson, D. International Handbook of Education for the Changing World of Work bridging Academic and Vocating Learning. Germany: UNESCO-UNEVOC

Clarke, L. \& Winch C. (2007). International approaches, developments and systems. Madison Avenue, New York: Routledge.

Depdiknas. (2005). Peraturan Pemerintah Republik Indonesia Nomor 19, Tahun 2005, tentang Standar Nasional Pendidikan.
Depdiknas. (1990). Peraturan Pemerintah RI Nomor 29, Tahun 1990, tentang Pendidikan Menengah.

Depdiknas. (2005). Undang-undang RI Nomor 14, Tahun 2005, tentang Guru dan Dosen.

Depdiknas. (2003). Undang-undang RI Nomor 20, Tahun 2003, tentang Sistem Pendidikan Nasional.

Deseco. (2005). Defining and selecting key competencies.

Diakses tanggal 15 Januari 2014 dari Www. Oecd.Org/Edu/Statistics/Deseco.

Direktorat P2TK Dikmen Kemdikbud. (2013). Panduan pelaksanaan program talent scouting guru SMK 2013. Depdiknas: Jakarta.

Fisher, R. And Webb, K. (2006). Subject specialist pedagogy and initial teacher training for the learning and skills sector in england: the context, a response and some critical issues. The Journal of Further and Higher Education. 30 (4) 337-349.

Iskandar, Fuad. (2010). Evaluasi pelaksanaan program pendampingan penyelenggaraan pendidikan kejuruan Direktorat Pembinaan SMK (Studi Kasus di Universitas Sebelas Maret). Tesis, tidak dipublikasikan. Universitas Indonesia.

Pavlova, M. (2009). Technology and vocational education for sustainable development. Queensland Australia: Spinger.

Smith, E. (2009). Teacher, instructors and trainers: an australian focus. Maclean, R., Wilson, D. International Handbook of Education for the Changing World of Work brdidging Academic and Vocating Learning. Germany: UESCO-UNEVOC

Sudira, Putu, MP. (2009). Pendidikan vokasi suatu pilihan. Diakses tanggal 17 Februari 2014 dari http://blog.uny.ac.id/putupanji/2009/03/17/pendidikan-vokasisuatupilihan.

Zamroni. (2001). Pradigma pendidikan masa depan. Yogyakarta: Bigraf Publishing. 